\title{
Impact of Work Climate and Workers' Satisfaction in COBA SA in Portugal
}

\author{
Amândio Baía ${ }^{1 *} \quad$ Márcia Ventura ${ }^{2}$ \\ 1.School of Technology and Management - Guarda Polytechnic - Portugal \\ UDI - Research Unit for Inland Development of Guarda \\ 2.Master in Management - Portugal \\ COBA-Portugal \\ * E-mail of the corresponding author: baia@ipg.pt
}

\begin{abstract}
The Work Climate represents the perception that workers have of the way a company offers the right conditions for them to develop their work in the best way. A positive organizational climate drives and sustains employee satisfaction and high performance. This investigation, supported by a questionnaire, presents a case study to workers at a COBA company, that is a world leader in the production of wires used in the car wiring harness, intending to understand their work climate and propose improvement measures.Although the overall classification of the Work Climate and the Worker Satisfaction in COBA is quite good, still exists opportunities for improvement. Our findings suggest that from the three dimensions, namely Safety, Hygiene and Health Conditions at Work, Motivation and Work Organization, considered in the Work Climate, only the first two dimensions influence the Worker Satisfaction. Motivation is the variable that most strongly predicts the perception of worker satisfaction. This study also reveals that the sociodemographic profiles are a key factor to consider, as the relationships between work climate dimensions and worker satisfaction vary across workers segments.No differences were found in the satisfaction of the workers related to age and contract type. On the other hand, workers, male, divorced, with more children, with a lower educational level, with less tenure and the ones that work in shifts, reported lower perception of the work climate and are less satisfied.
\end{abstract}

Keywords: Work Climate, Satisfaction, Motivation, Quality of life at work

DOI: $10.7176 / \mathrm{EJBM} / 13-18-02$

Publication date:September $30^{\text {th }} 2021$

\section{Introduction}

Evaluating employees' perception of the environment in which they develop their activities is a very common practice in contemporary organizations. This kind of evaluation per se allows an organization to diagnose and adopt measures that could, possibly, result in greater overall employee satisfaction Ahmad et. al., 2018).

After assessing the work climate and applying corrective measures to company problems, an increase in productivity, a lower rate of absenteeism, reduced functional rotation and greater client satisfaction can be expected, among other aspects that may impact the result (Limm et al., 2012).

A positive climate has been found to have a strong linkage with outcomes including innovation, employee diligence, employee performance, organizational commitment, and job satisfaction, and also it has been linked to the decrease of problems including hostility, interpersonal aggression, employee burnout, obstructionism, absenteeism and deception (Huang et al., 2010; Lambert et al., 2012). Hence, work climate is examined as a satisfaction predictor in the present study.

This article aims to understand the implications that the work climate has on workers' satisfaction. The study focused on the multinational COBA (fictitious name), located in Portugal, but which operates in other thirteen countries, and proposes to measure the implication of the work climate in the satisfaction of workers, a determining factor in performance. The company COBA produces, in three shifts, wires used in the car wiring harness, a highly competitive market, where productivity and quality are crucial.

To this end, a simple random sample of workers from different departments was chosen to whom a questionnaire was administered to assess their satisfaction with the work climate and propose corrective measures to strengthen their satisfaction and as a consequence their performance.

\section{Literature Review}

Human resources are the most important factor in an organization (Ivancevich, 2014). Regardless of the type of organization, all firms need to manage their workforce using appropriate policies and practices. Organizations can be more effective if they manage their human resources in such a way that they deliver the right number of people with the appropriate behaviour's, the necessary competencies, and the right levels of motivation to the organization (Schuler, 2015). A good company can successfully use the expertise and qualifications of its employees.

Individual talents alone would not enable them to operate at a high level of efficiency unless there is an 
incentive structure in place that promotes their internal incentives and therefore motivates them to work very hard (Chandrawaty \& Widodo, 2020).

According to Kuenzi, Mayer and Greenbaum (2020), the work climate can be used as a tool to help employees understand the work environment, helping them to understand how they should behave. For Segatto and Wachowicz (2017), the work climate is nothing more than how the workers perceive the company and how they react within it. They also say that the work climate is related to the degree of satisfaction of its employees, that is, a company that does not conduct a survey of the work climate frequently, and correctly, can lead to negative results in organizations and unmotivated employees, as there is no knowledge of employee dissatisfaction.

Work Climate refers to the employees' shared perceptions and the meaning they attach to the policies, practices and procedures they experience in their workplace, as well as to the behaviours they observe being rewarded, supported and expected regarding the human resources of the organisation (Ahmad et al., 2018; Cygler et al., 2018; Schneider et al., 2016; Ivancevich et al., 2014).

According to $\mathrm{Lu}$ et al. (2016), organizations should pay attention to the work climate components with which they can influence the work engagement of their employees. This is especially important in the firms of industry 4.0 (Hariharasudan \& Kot, 2018; Kovacs \& Kot, 2016).

Much evidence shows that a positive work climate in a workplace has been associated with an increased competitive advantage, productivity, performance, customer satisfaction, and hiring selectivity, as well as decreased absenteeism, turnover, injury/accident rates, and health care cost (Rozman et al., 2019; Berberoglu, 2018; Maamari \& Majdalani, 2017; Shuck \& Reio, 2017; Limm et al., 2011). Work climate also helps in determining organizational success (Purohit \& Wadhwa, 2012; Paais, \& Pattiruhu, 2020). Viitala et al. (2015), Albrecht et al. (2018) and Schaufeli (2016) argue that employees working in organisations with suitable work climates are more likely to be satisfied and engaged. Murphy (2015) noted that people in positive work environments outperform those who work in negative work climates by 10 to 30 per cent.

Since work climate surveys represent measurements of employee satisfaction, is important to look for the concept of job satisfaction. Job satisfaction is the most studied field of organizational behaviour (Anwar, 2017). Judge et al. (2017) mention that satisfaction is a positive frame of mind that is reflected by the employee's opinion regarding work or the climate of his workplace, or in another way job satisfaction is an assessment of the favourability of a job. From the organization's point of view, good job satisfaction can lead to better performance of the workers which affects the result of the company (Smith et al. 2020).

Satisfied employees are a precondition for increasing productivity, responsiveness, quality, and recognition service (Kiarie, Maru, \& Cheruiyot, 2017), as well as employee performance and motivational levels (Khan, Nawaz, Aleem, \& Hamed, 2012).

The level of job satisfaction is affected by intrinsic and extrinsic motivating factors, the quality of supervision, social relationships with the workgroup in which individuals succeed or fail in their work. It is believed that the behaviour that helps the firm to be successful is most likely to happen when the employees are well motivated and feel committed to the organization, and when the job gives them a high level of satisfaction (Paais, \& Pattiruhu, 2020). The research also showed that the key factors affecting job satisfaction are career opportunities, job influence, teamwork and job challenge (Riyadi, 2020).

Through the creation of a positive and cooperative atmosphere within an organization and the design of an effective compensation package for employees leads to satisfaction, motivation and commitment to the improvement of the overall functioning of an organization (Stefurak et al. 2020). Many companies offer familyfriendly benefits that employees need to balance life and work, which include job sharing, flexitime, telecommunicating, etc. (Ganapathi, 2016). Azeem and Akhtar (2014) showed that work-life balance, job satisfaction, and organizational commitment showed a significant and strong relationship. The amount of influence given by work-life balance and job satisfaction on organizational commitment is 37\% (Anwar, 2017).

Increasing motivation, commitment and engagement levels are key organizational aspects nowadays. The importance of employee satisfaction and work motivation is growing all the time in companies. While motivation is principally concerned with goal-directed behaviour, and job satisfaction is related to fulfilment, which we acquire through different rewards and job-related activities. Employees are likely to stay in organizations where they believe that their capabilities, contributions and efforts are appreciated (Febrianti \& Se, 2020). The social context will also affect the motivation level (Anwar, 2017). Motivation theories can be implemented in the company's human resource policies to get the best out of the employees (Ali, 2021). It is possible that an employee is enjoying all the job-related activities but still he has a low level of motivation (Ha et al. 2020).

Recognition, as one of the most significant sources of organizational mobilization and participation (Alrawahi et al. 2020), is essential to the success and sustainability of organizational change (Andavar \& Ali, 2020) and acts as a base for learning organizations (Sobaih \& Hasanein, 2020).

In sum, work climate is instrumented to higher owner's employee productivity, commitment, satisfaction 
and better human relations (Kumar-Bamel et al., 2013; Maamari \& Majdalani, 2017).

Work satisfaction is a pleasurable emotional state that results from a sense of achievement in the workplace (Cronley, \& Kim, 2017).

\section{Methodology}

This study focuses aims to understand the effect of work climate on the satisfaction of the workers in an international company - COBA, located in Portugal but operates in 13 other countries. It is a world leader in the production of wires used in the car wiring harness and has 800 workers.

As a research instrument, a questionnaire with two sections was used. The first section includes questions to determine the sociodemographic profiles: gender, age, marital status, number of children, educational level, time working in the company, work schedule, type of employment contract and work department.

The second section of the questionnaire was a 21-item scale measuring the three dimensions: Conditions of Safety, Hygiene and Health at Work, Organization of Work and Motivation. Also, was included a question about the level of Global Satisfaction in the company. In this section respondents were required to rate on a 5-point Likert scale for data collection with " 1 " as "strongly disagree" and " 5 " as "strongly agree".

The questionnaire was pilot tested by ten workers. Respondents in the pilot test did not have problems with the questionnaire, although minor changes in the wording were suggested. There were distributed at random 400 questionnaires to the COBA workers and 291 valid questionnaires were obtained, which corresponds to a response rate of $72.75 \%$.

In determining the sample size, we had a significance level of 5\% and a sampling error of $4.23 \%$.

Based on the literature on satisfaction assessment models, we designed a conceptual research model presented in Figure 1 to test the impact of the work climate on workers satisfaction.

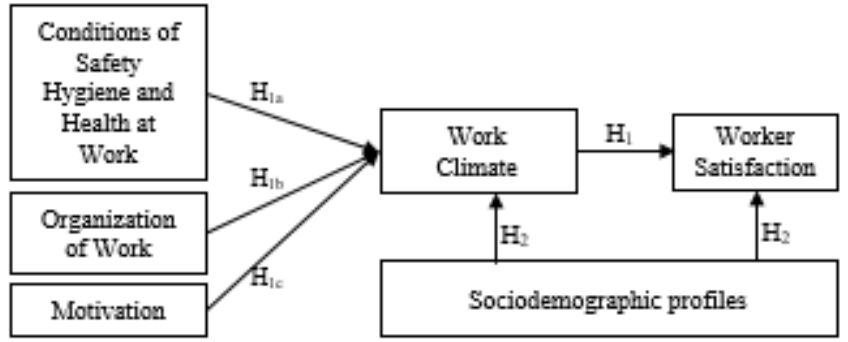

Figure 1 - Conceptual research model

The following hypothesis provided the scope and depth of the study were formulated:

H1: All three work climate dimensions have a significantly positive influence on worker satisfaction.

H2: Sociodemographic profiles impact the evaluation of the workers with the dimensions of the Work Climate and Worker Satisfaction.

To improve the workers' satisfaction item responses were classified as green if its average $>4$, yellow if its $3 \leq$ average $\leq 4$ and red if it is average $<3$. Green items need to be stimulated to be maintained and improved. Yellow items need attention to improve to green. Items classified red need special action measures and immediate intervention to be improved.

To test the consistency of the sample, the Kaiser-Meyer-Olkin test (KMO) was used. The reliability of the dimensions and the questionnaire, in general, was calculated using Cronbach's alpha coefficient.

To assess of group average differences of the sociodemographic variables related to the workers' satisfaction and the dimensions of the Work Climate, one-way ANOVA, the Mann-Whitney U test, and the Kruskal-Wallis non-parametric, followed by multiple comparisons of the order means with ANOVA Tukey, as described by Maroco (2018) were used.

All statistical work was performed on IBM SPSS software (v25 - SPSS Inc Chicago, IL) and Excel (Microsoft Office 2015, Microsoft Corporation).

\section{Analysis and Discussion of the Results}

The sociodemographic profile of the 291 respondents is described in Table 1 . The majority of the respondents are male $(84.88 \%), 64.60 \%$ have age between $26-45$ years, $52.58 \%$ are married, $44.33 \%$ have 1 or 2 children, $34.71 \% \%$ has the secondary as the Educational Level, $43.99 \%$ are working in the company for less than 5 years, $62.89 \%$ works in shifts, $64.95 \%$ has a contract without a certain term and $20.96 \%$ works in the Industrial Performance Department. 
Table 1 - Sociodemographic Profile of Respondents

\begin{tabular}{|c|c|c|c|}
\hline Category & Items & Frequency & $(\%)$ \\
\hline \multirow{2}{*}{ Gender } & Male & 247 & 84.88 \\
\hline & Female & 44 & 15.12 \\
\hline \multirow{4}{*}{ Age (years) } & $\leq 25$ & 31 & 10.65 \\
\hline & $26-45$ & 188 & 64.60 \\
\hline & $46-55$ & 58 & 19.93 \\
\hline & $\geq 56$ & 14 & 4.81 \\
\hline \multirow{4}{*}{ Marital Status } & Not Married & 120 & 41.24 \\
\hline & Married & 153 & 52.58 \\
\hline & Widow & 18 & 6.19 \\
\hline & Divorced & 120 & 41.24 \\
\hline \multirow{4}{*}{ Number Children } & None & 156 & 53.61 \\
\hline & 1 & 76 & 26.12 \\
\hline & 2 & 53 & 18.21 \\
\hline & 3 or more & 6 & 2.06 \\
\hline \multirow{7}{*}{ Educational Level } & 1st Cycle & 16 & 5.50 \\
\hline & 2nd Cycle & 24 & 8.25 \\
\hline & $3^{\text {rd }}$ Cycle & 56 & 19.24 \\
\hline & Secondary & 101 & 34.71 \\
\hline & Bachelor & 69 & 23.71 \\
\hline & Graduate & 4 & 1.37 \\
\hline & Master & 21 & 7.22 \\
\hline \multirow{4}{*}{$\begin{array}{l}\text { Years } \\
\text { Company }\end{array}$} & $\leq 1$ & 31 & 10.65 \\
\hline & $2-5$ & 128 & 43.99 \\
\hline & $6-15$ & 106 & 36.43 \\
\hline & $\geq 16$ & 26 & 8.93 \\
\hline \multirow{2}{*}{ Work Schedule } & Fixed & 108 & 37.11 \\
\hline & Shifts & 183 & 62.89 \\
\hline \multirow{3}{*}{$\begin{array}{l}\text { Employee } \\
\text { Contract }\end{array}$} & Fixed Term Contract & 100 & 34.36 \\
\hline & Contract Without a certain term & 189 & 64.95 \\
\hline & Other & 2 & 0.69 \\
\hline \multirow{17}{*}{ Department } & Environment and safety & 3 & 1.03 \\
\hline & $\mathrm{R} \& \mathrm{D}$ & 7 & 2.41 \\
\hline & Projects / Engineering & 2 & 0.69 \\
\hline & Purchasing & 2 & 0.69 \\
\hline & Logistics & 9 & 3.09 \\
\hline & Quality & 11 & 3.78 \\
\hline & Management Control & 15 & 5.15 \\
\hline & Maintenance & 39 & 13.40 \\
\hline & Recycling & 16 & 5.50 \\
\hline & Direction & 10 & 3.44 \\
\hline & Industrial Performance & 61 & 20.96 \\
\hline & Human Resources & 51 & 17.53 \\
\hline & Finance & 6 & 2.06 \\
\hline & Metal production & 43 & 14.78 \\
\hline & Sales & 6 & 2.06 \\
\hline & IT & 8 & 2.75 \\
\hline & Extrusion production & 2 & 0.69 \\
\hline
\end{tabular}

As can be seen in Table 2, 18 items $(85.71 \%)$ of the Work Climate dimensions had a yellow classification. Only one item belonged to the Motivation dimension, has a red classification - Appropriate Remuneration for the Function. The two green items belong to the dimension Safety, Hygiene and Health Conditions at Work. The overall workers' perception of the Work Climate lies in the yellow classification (mean=3.52) meaning that can be improved and evolve to a green rating. The global satisfaction of the COBA workers also lies in the yellow classification (mean=3.49). 
Table 2 - Mean and Standard Deviation of the Dimensions' Items

\begin{tabular}{|c|c|c|}
\hline Variables & Mean & $\begin{array}{l}\text { Standard } \\
\text { Deviation }\end{array}$ \\
\hline Safety, Hygiene and Health Conditions at Work & 3.68 & 0.582 \\
\hline $\begin{array}{l}\text { Installation conditions (lighting, noise, vibrations, thermal environment temperature and } \\
\text { environment). }\end{array}$ & 3.25 & 0.852 \\
\hline Canteen conditions (physical, food, service, schedule, hygiene). & 4.01 & 0.774 \\
\hline Chemical and Biological Factors (exposure to toxic products). & 3.43 & 0.916 \\
\hline $\begin{array}{l}\text { Health at work (support from the occupational doctor or nurse, conducting admission } \\
\text { tests, periodic and occasional, health and well-being plans and actions). }\end{array}$ & 4.01 & 0.783 \\
\hline $\begin{array}{l}\text { Provision of personal protective equipment (appropriate clothing, steel toe boots, } \\
\text { earbuds or earmuffs, goggles and gloves (when needed)). }\end{array}$ & 3.70 & 0.926 \\
\hline Organization of Work & 3.52 & $\mathbf{0 . 5 8 6}$ \\
\hline Opportunities to develop new skills and training. & 3.46 & 0.831 \\
\hline Recognition and appreciation of the work done. & 3.43 & 0.777 \\
\hline Integration of new employees. & 3.81 & 0.671 \\
\hline Degree of autonomy in planning/executing functions. & 3.65 & 0.645 \\
\hline Possibility to participate with ideas for a better function of the job. & 3.45 & 0.814 \\
\hline Team spirit in the performance of their role. & 3.81 & 0.69 \\
\hline Performance evaluation system (fair and useful). & 3.23 & 0.917 \\
\hline Reconcile work with the family. & 3.31 & 1.013 \\
\hline Motivation & 3.35 & 0.648 \\
\hline Career progression. & 3.27 & 0.951 \\
\hline Appropriate remuneration for the function. & 2.86 & 0.908 \\
\hline Work environment among colleagues. & 3.82 & 0.671 \\
\hline Relationship with superiors. & 3.57 & 0.841 \\
\hline Workers' problems (consideration and importance given). & 3.18 & 0.895 \\
\hline Carrying out initiatives that promote conviviality. & 3.74 & 0.669 \\
\hline Working hours. & 3.04 & 1.061 \\
\hline Equal treatment in the organization. & 3.29 & 0.918 \\
\hline Global Satisfaction Level at COBA & 3.49 & 0.745 \\
\hline
\end{tabular}

Regarding the sample surveyed by the COBA organizational units, the comparison between the surveyed sample and the population about the workplace (Table 3) shows the absence of significant differences between them, concluding that the collected sample and the population are homogeneous.

Table 3 - Comparison between the population and the sample of collaborators per organic unit

Population

\begin{tabular}{|c|c|c|c|c|}
\hline \multirow[b]{2}{*}{ Workplace } & & \\
\hline & Frequency & $\%$ & Frequency & $\%$ \\
\hline Environment and safety & 4 & 0.63 & 3 & 1.03 \\
\hline$R \& D$ & 10 & 1.58 & 7 & 2.41 \\
\hline Projects / Engineering & 3 & 0.47 & 2 & 0.69 \\
\hline Purchasing & 5 & 0.79 & 2 & 0.69 \\
\hline Logistics & 11 & 1.74 & 9 & 3.09 \\
\hline Quality & 19 & 3.00 & 11 & 3.78 \\
\hline Management Control & 37 & 5.84 & 15 & 5.15 \\
\hline Maintenance & 86 & 13.56 & 39 & 13.40 \\
\hline Recycling & 39 & 6.15 & 16 & 5.50 \\
\hline Direction & 21 & 3.31 & 10 & 3.44 \\
\hline Industrial Performance & 131 & 20.66 & 61 & 20.96 \\
\hline Human Resources & 127 & 20.03 & 51 & 17.53 \\
\hline Finance & 8 & 1.26 & 6 & 2.06 \\
\hline Metal production & 105 & 16.56 & 43 & 14.78 \\
\hline Sales & 12 & 1.89 & 6 & 2.06 \\
\hline IT & 11 & 1.74 & 8 & 2.75 \\
\hline Extrusion production & 5 & 0.79 & 2 & 0.69 \\
\hline Total & 634 & 100.00 & 291 & 100.00 \\
\hline
\end{tabular}

[Chi-square $=11.232(\mathrm{p}>0.05)]$

The Kaiser-Mayor-Olkin (KMO) measure of sampling adequacy was 0.933 and the Cronbach's $\alpha$ was 0.943 being that all dimensions are superior to 0.70 (Table 4) meaning that the questionnaire's reliability and validity 
were deemed effective (Parsian \& Dunning, 2009).

Table 4 - Reliability Statistics

\begin{tabular}{|c|c|c|c|c|}
\hline Construct & $\begin{array}{l}\text { Number of } \\
\text { Items }\end{array}$ & $\mathrm{O}^{\mathrm{KM}}$ & $\begin{array}{l}\text { Bartlett Test } \\
\text { (Significance) }\end{array}$ & $\begin{array}{l}\text { Cronbach } \\
\text { Alfa }\end{array}$ \\
\hline $\begin{array}{l}\text { Safety, Hygiene and Health Conditions } \\
\text { at Work }\end{array}$ & 5 & 0.718 & $313.917(\rho=0.000)$ & 0.713 \\
\hline Organization of Work & 8 & 0.866 & $1060.890(\rho=0.000)$ & 0.874 \\
\hline Motivation & 8 & 0.889 & $1104.243(\rho=0.000)$ & 0.883 \\
\hline Questionnaire & 21 & 0.933 & $3631.383(\rho=0.000)$ & 0.943 \\
\hline
\end{tabular}

Scores for the 3 dimensions showed a strong positive correlation with each other (Table 5), meaning that the dimensions all made an approximately equal contribution to the overall Work Climate assessment.

Table 5 - Pearson Correlation Matrix of the three Dimensions

\begin{tabular}{|c|c|c|c|c|c|}
\hline & & 1 & & 2 & 3 \\
\hline 1. Safety, Hygiene and Health Conditions at Work & & 1 & & & \\
\hline 2. Organization of Work & $0.738^{* *}$ & $\left(\mathrm{R}^{2}=0.545\right)$ & & 1 & \\
\hline 3. Motivation & $0.674^{* *}$ & $\left(\mathrm{R}^{2}=0.454\right)$ & $0.852^{* *}$ & $\left(\mathrm{R}^{2}=726\right)$ & 1 \\
\hline
\end{tabular}

[Correlations is significant at the 0.01 level (2-tailed test)]

Table 6 shows the Linear Regression Model between the three independent variables of the Work Climate and the dependent variable Worker Satisfaction. The $\mathrm{R}^{2}=0.691$ meaning that $69.10 \%$ of the change in the dependent variable Worker Satisfaction, can be explained by the three independent variables, namely, Safety, Hygiene and Health Conditions at Work, Organization of Work, and Motivation. The F value is equal to 214.329 $(\mathrm{p}<0.001)$ which shows that the Multiple Linear Regression is significant and at least one of the three independent variables has a significant relationship with Worker Satisfaction.

The dimensions Safety, Hygiene and Health Conditions at Work and Motivation have a significant positive statistical effect on worker satisfaction, so hypotheses $\mathrm{H}_{1 \mathrm{a}}$ and $\mathrm{H}_{1 \mathrm{c}}$ are supported. However, there is no statistically significant evidence that the coefficient of the variable Organization of Work is different from zero, or otherwise that this dimension contributes to the assessment of COBA's Worker Satisfaction, so hypothesis $\mathrm{H}_{1 \mathrm{~b}}$ is rejected. The Motivation dimension $(\beta=0.601)$ is the variable that most strongly predicts the perception of worker satisfaction (Table 6).

The Standardized Regression Model is:

Worker Satisfaction $=-0.148+0.224$ (Safety, Hygiene and Health Conditions at Work) +0.143 (Organization of Work $)+0.691$ (Motivation)

Table 6 - Linear Regression Model

\begin{tabular}{lccccccc}
\hline \multicolumn{1}{c}{ Predictor variable } & B & SE & Beta & t & Sig & Hypothesis & Remarks \\
\hline Intercept & -0.148 & 0.164 & & -0.901 & 0.368 & - & - \\
Safety, Hygiene and Health Conditions at Work & 0.224 & 0.063 & 0.175 & 3.578 & 0.000 & $\mathrm{H}_{1 \mathrm{a}}$ & Supported \\
Organization of Work & 0.143 & 0.088 & 0.113 & 1.633 & 0.104 & $\mathrm{H}_{1 \mathrm{~b}}$ & Rejected \\
Motivation & 0.691 & 0.073 & 0.601 & 9.524 & 0.000 & $\mathrm{H}_{1 \mathrm{c}}$ & Supported \\
\hline
\end{tabular}

$\mathrm{R}=0.832 ; \mathrm{R}^{2}=0.691 ;$ Adjusted $\mathrm{R}^{2}=0.688 ; \mathrm{F}=214.329(\mathrm{p}<0.001)$

These results agree with the results of Schulte et al. (2015) and Freire (2019) that point out that a good policy on Safety, Hygiene and Health Conditions at Work is important for the well-being of employees in their work environment.

Contrary to what was reported by Tesluk, Farr and Klein (2011) and Santo (2016), the relationship between the Work Organization and Worker Satisfaction was not confirmed in this study.

Francisco (2018), Jusmin, Said, Bima, and Alam (2016), Zacher and Yang (2016) and Putra (2019) report that motivation is seen as an outlet to improve professional performance and employee satisfaction, contributing to higher productivity of the organization. A good work climate leads to satisfied and motivated employees.

To improve the work climate provided by the COBA and leave some recommendations, we tried to find significant differences in the sociodemographic factors related to each of the three dimensions of the Work Climate model and the Worker Satisfaction.

The Kolmogorov-Smirnov test $(\mathrm{p}<0.05)$ shows that all the dimensions of the Work Climate and Worker Satisfaction are not normally distributed. Then we used the nonparametric tests to assess the differences.

A Kruskal-Walls $H$ test revealed no significant differences associated with Age and Contract Type ( $\mathrm{p}>0.05)$. In contrast, there were found significant differences in other sociodemographic factors.

Gender - The Mann-Whitney $U$ test showed that gender has a statistically significant change in Worker Satisfaction $(U=3694, p=0.000)$, and in the dimensions Safety, Hygiene and Health Conditions at Work $(U=3566, p=0.000)$, Organization of Work $(U=3944, p=0.004)$ and Motivation $(U=3632, p=0.000)$.

Indeed, all respondents have an average rating in yellow. However, female respondents have a better perception of COBA's Work Climate in all dimensions and they are also more satisfied than male respondents. It is reported 
that the majority of female respondents perform administrative activities, and few women work in shifts (Table 7).

Table 7 - Means Gender*Work Satisfaction and Dimensions

\begin{tabular}{lcccc}
\hline Gender & \multicolumn{4}{c}{ Mean } \\
& $\begin{array}{c}\text { Work } \\
\text { Satisfaction }\end{array}$ & Safety, Hygiene and Health Conditions at \\
Work & $\begin{array}{c}\text { Organization of } \\
\text { Work }\end{array}$ & Motivation \\
\hline Female & 3.91 & 4.00 & 3.79 & 3.70 \\
Male & 3.42 & 3.63 & 3.47 & 3.28 \\
\hline
\end{tabular}

According to Zou (2018) in the job satisfaction literature, women, though argued to be short-changed in the work world, are more satisfied with their job than men. Ferreira (2015) suggests the possibility that women have lower expectations when compared to men and, consequently, they are easier to achieve and increasing the level of satisfaction in the work.

Marital Status - The Kruskal-Wallis H test $(\chi 2=9.469, p=0.009)$ showed that there was a statistically significant difference only at the Worker Satisfaction. The Anova Tukey test $(\mathrm{p} \leq 0.05)$ showed that married $(\operatorname{mean}=3.55)$ and not married workers (mean $=3.50$ ) related higher satisfaction than divorced (mean=3.00) ones.

Number of Children - The Kruskal-Wallis H test $(\chi 2=10.210, p=0.017)$ showed that there was a statistically significant difference only at the Worker Satisfaction. The ANOVA Tukey test $(\mathrm{p} \leq 0.05)$ showed that workers with 3 or more children (mean=2.67) related to being less satisfied, even rated satisfaction in red, than the workers with fewer children $(3.47 \leq$ mean $\leq 3,62)$.

Educational Level - The Kruskal-Wallis $\mathrm{H}$ test $(\mathrm{p}<0.05)$ showed that there was a statistically significant difference in Worker Satisfaction and at all dimensions of the Work Climate. The ANOVA Tukey test $(\mathrm{p} \leq 0.05)$ shows that the workers with an educational level less than Bachelor are less satisfied than the workers with higher educational levels. The workers with the $1^{\text {st }}$ Educational level even rated in the Worker Satisfaction (mean=2.88) and the dimension Motivation (mean=2.97) in red. These workers work in the production lines and by shifts. The workers with higher educational levels generally develop administrative work.

These results agree with the findings of Ferreira (2015) that states that the higher the workers' qualifications, the higher the satisfaction levels achieved, due to the association that is established between them and the new career and promotion opportunities.

Years in Company - The Kruskal-Wallis H test $(\mathrm{p}<0.05)$ showed that there was a statistically significant difference in the Worker Satisfaction and the dimensions Safety, Hygiene and Health Conditions at Work and Motivation. From the ANOVA Tukey test $(p \leq 0.05)$ it can be concluded that the workers who have been with the company for sixteen or more years (more tenure) say they are more satisfied (mean=3.77).

These results converge with the results of numerous studies that have found that employee satisfaction is closely related to the length of service (Bogan \& Dedeoglu, 2017). Also, Henriques (2009) finds that there is a significant relationship between the length of service and professional performance, in this case, it is the workers with more and less time of service who are more satisfied and motivated.

Work Schedule - The Mann-Whitney U test showed that work schedule has a statistically significant change in Worker Satisfaction $(\mathrm{U}=5659.5, \mathrm{p}=0.000)$, and in the Dimensions Safety, Hygiene and Health Conditions at Work $(U=5696, p=0.000)$, Organization of Work $(U=4577, p=0.004)$ and Motivation $(U=3787, p=0.000)$.

All respondents have an average yellow rating. However, respondents with a fixed schedule, have a better perception of COBA Work Climate in all dimensions and are also more satisfied (mean=3.86) than respondents who work on a shift schedule (mean=3.28).

The number of working hours, shift work, night work, etc., are determinants for the achievement of a good work/life balance, subsequently playing a significant role in job satisfaction (Eagan et al., 2015; Roy, 2017)

Martins and Martins (1999), refer that studies on the satisfaction with the social and family life of workers with shift schedules and workers with fixed schedules concluded that satisfaction decreases in five years in the case of shift workers, as opposed to fixed-time workers, who did not reveal any changes. Still, concerning family problems, it can be concluded, from the comparison of day workers with ex-shift workers, that the proportion of divorces is significantly higher in the latter.

Department - The Kruskal-Wallis $\mathrm{H}$ test $(\mathrm{p}<0.05)$ showed that there was a statistically significant difference in Worker Satisfaction and all dimensions. From the ANOVA Tukey test $(p \leq 0.05)$ it can be concluded that the workers of the Maintenance Department are the least satisfied in the Work Satisfaction (mean=2.75) and the Motivation (mean=2.89) dimension, being classified in red, followed by the Production and Quality departments. In general, there are the departments with activities that are not linked to the production that have a better rating in all dimensions and also at the Global Satisfaction level. For example, the Management Control Department has the best rating in all dimensions and also at the Global Satisfaction (mean=4.50) level (Table 8). 


\begin{tabular}{|c|c|c|c|c|}
\hline Department & $\begin{array}{c}\text { Work } \\
\text { Satisfaction }\end{array}$ & $\begin{array}{l}\text { Safety, Hygiene and Health } \\
\text { Conditions at Work }\end{array}$ & $\begin{array}{c}\text { Organization of } \\
\text { Work }\end{array}$ & Motivation \\
\hline Environment and safety & 4.00 & 4.13 & 4.13 & 3.71 \\
\hline $\mathrm{R} \& \mathrm{D}$ & 3.40 & 3.91 & 3.63 & 3.28 \\
\hline Projects / Engineering & 3.67 & 3.60 & 3.52 & 3.73 \\
\hline Purchasing & 4.14 & 4.37 & 4.18 & 4.11 \\
\hline Logistics & 3.82 & 3.66 & 3.66 & 3.57 \\
\hline Quality & 3.37 & 3.41 & 3.22 & 3.14 \\
\hline Management Control & 4.50 & 4.20 & 3.63 & 3.75 \\
\hline Maintenance & 2.75 & 3.25 & 3.24 & 2.89 \\
\hline Recycling & 3.83 & 4.07 & 3.81 & 3.52 \\
\hline Direction & 4.50 & 4.81 & 4.75 & 4.81 \\
\hline Industrial Performance & 3.60 & 3.76 & 3.79 & 3.59 \\
\hline Human Resources & 4.50 & 4.25 & 4.30 & 4.34 \\
\hline Finance & 3.78 & 3.89 & 3.75 & 3.71 \\
\hline Metal production & 3.33 & 3.67 & 3.37 & 3.12 \\
\hline Sales & 4.00 & 4.10 & 3.75 & 3.56 \\
\hline IT & 3.91 & 4.02 & 3.84 & 4.03 \\
\hline Extrusion production & 3.22 & 3.56 & 3.39 & 3.10 \\
\hline
\end{tabular}

\section{Suggestions and Recommendations for Management}

Managers can use the founded results to improve the planning of the human resource strategy and implement their leadership style more effectively to create better worker satisfaction.

In consequence of the findings, we propose the following suggestions:

- Work Conditions Improvement - light and temperature conditions in warehouses and production lines will help to alleviate the stress. Rozman et al. (2020) in their research found out that stress has a strong and negative impact on employee relationships and also a negative impact on worker satisfaction. This dimension refers to environmental hazards and to factors related to posture-related risks, which become relevant factors in the health of employees, a fundamental aspect of job hygiene and satisfaction (Devonish, 2018; Koh et al., 2017).

Provide workers with more personal protection equipment, and of better quality.

- Empowerment - decentralization of power to allow greater participation of workers in the decision-making process. Workers are likely to stay in organizations where they believe that their capabilities, contributions and efforts are appreciated (Febrianti \& Se, 2020).

- Promotion Expectations - create in the workers, especially the ones with less tenure, the feeling that their effort will result in a given performance with the consequent reward that they value - for example, the possibility of career progression, recognition of the work developed in the communication channels, diplomas, medals, etc. Riyadi (2020) shows that the key factors affecting job satisfaction are career opportunities, job influence, teamwork and job challenge. According to Bogan and Dedeoglu (2017), shorter-tenure employees are more sensitive to work-related variables, such as leadership, and need closer communication with their supervisors.

- Remuneration Adequacy - giving productivity prizes to production teams that at the end of the month produced more kilometres of yarn with less scrap percentage, could contribute to improving the perception that workers have about the remuneration appropriate to the function (mean=2.86). Stefurak et al. (2020) say that design an effective compensation package for employees leads to satisfaction, motivation and commitment to the improvement of the overall functioning of an organization. The importance of earnings as a motivational factor has been widely studied in the literature (Suzuki et al., 2018).

- $\quad$ Training - give more training opportunities, especially to employees who have less education, so that they do not feel undervalued and become more motivated. Workers who know they have the opportunity to improve their skills and rise within the organisation may be more satisfied with their work (Gobal et al., 2018).

- Socialization Opportunities - developing socialization activities with workers and their families. Parties, picnics, walks, quality of life campaigns, promoting lectures focused on well-being and healthy eating, which stimulate physical exercise practices and alert to the dangers of harmful habits such as smoking and alcoholism. are good ways to encourage workers and improve their satisfaction. Berberoglu (2018) states that employer behaviour is affected by a wide range of organisational characteristics and social relationships. 


\section{Conclusions}

Understanding the relationship between Work Climate and Worker Satisfaction will help to create an appropriate working environment essential for organizational and worker performance.

This study in COBA organization helps managers and practitioners to understand how various dimensions of work climate can impact work satisfaction. It elaborates the relationship between three dimensions of Work Climate, namely Safety, Hygiene and Health Conditions at Work, Organization of Work, and Motivation in the Worker Satisfaction. Also, the implications of the sociodemographic profiles in the Work Climate and on Worker Satisfaction were studied.

The results help users to better understand the importance to create a positive Work Climate and are indicating a broader picture of the organisational climate conditions in the European Union.

Although the overall classification of the Work Climate (mean=3.52) and the Worker Satisfaction (mean=3.49) in COBA is quite good, still exists opportunities for improvement. Our findings suggest that only the dimensions Safety, Hygiene and Health Conditions at Work and Motivation influence Worker Satisfaction. Motivation is the variable that most strongly predicts the perception of worker satisfaction. They also reveal that the sociodemographic profiles are a key factor to consider, as the relationships between work climate dimensions and worker satisfaction vary across workers segments.

No differences were found in the satisfaction of the workers related to age and contract type. On the other hand, workers, male, divorced, with more children, with a lower educational level, with less tenure and the ones that work in shifts, reported lower perception of the work climate and are less satisfied. It is important to remember that females and workers with higher educational levels neither work in the production line nor by shifts.

Although this study provides a perspective on different aspects of the work climate, it has many limitations. It may not be possible to extrapolate the results to different national or sectoral settings since it was performed in one particular establishment. Further studies in other contexts, activities/industries and environments, that attempt to replicate this study, would therefore be necessary to confirm our findings.

Since COBA company has factories in other thirteen countries, would be very valuable, for future research, both for science, societies and organizations, to examine and compare the differences existent in Work Climate and Worker Satisfaction among these countries.

\section{References}

Ahmad, K. Z. B., Jasimuddin, S. M., \& Kee, W. L. (2018). Organizational climate and job satisfaction: Do employees' personalities matter? Management Decision, 56(2), 421-440. https:// doi.org/10.1108/MD-102016-0713

Albrecht, S., Breidahl, E., \& Marty, A. (2018). Organizational resources, organizational engagement climate, and employee engagement. Career Development International, 23(1), 67-85. https://doi.org/10.1108/CDI04-2017-0064.

Ali, B. J. (2021). Assessing (The impact) of an advertisement on customer decision making: Evidence from an educational institution.

Alrawahi, S., Sellgren, S. F., Salem A., Alwahaibi, N., \& Brommels, M. (2020). The application of Herzberg's two-factor theory of motivation to job satisfaction in clinical laboratories in Omani hospitals. Heliyon 6 (2020) e04829. https://doi.org/10.1016/j.heliyon.2020.e04829

Andavar, V., \& Ali, B. (2020). Rainwater for Water Scarcity Management: An Experience of Woldia University (Ethiopia). ANDAVAR, V., ALI, BJ, \& ALI, SA (2020). Rainwater for Water Scarcity Management: An Experience of Woldia University (Ethiopia). The Journal of Business Economics and Environmental Studies, 10(4), 29-34.

Anwar, K. (2017). Factors affecting stock exchange investment in kurdistan. The International Journal of Accounting and Business Society, 25(1), 32-37.

Azeem, S. M., \& Akhtar, N. (2014). The influence of work life balance and job satisfaction on organizational commitment of healthcare employees. International Journal of Human Resource Studies, 4(2), 18.

Berberoglu, A. (2018). Impact of organizational climate on organizational commitment and perceived organizational performance: Empirical evidence from public hospitals. BMC Health Services Research, 18(1), 1-9. https://doi.org/10.1186/s12913-018-3149-z

Bogan, E, \& Dedeoglu, B. B., (2017). The effects of perceived behavioural integrity of supervisors on employee outcomes: Moderating effects of tenure. Journal of Hospitality Marketing \& Management, 26(5), 511-531. doi:10.1080/19368623.2017. 1269711.

Chandrawaty, C., \& Widodo, W. (2020). The mediation mechanism effect of self-efficacy and achievement motivation on job satisfaction: The personality perspective. Journal of Xi'an University of Architecture \& Technology, 12, 258-266.

Cronley, C., \& Kim, Y. (2017). Intentions to turnover. Leadership \& Organization Development Journal, 38(2), 
194-209. Retrieved from. https://doi.org/10.1108/LODJ-10-2015-022.

Cygler, J., Sroka, W., Solesvik, M., \& De Rbkowska, K. (2018). Benefits and drawbacks of coopetition: The roles of scope and durability in competitive relationships. Sustainability, 10(8), 2688-2712. https://doi.org/10.3390/su10082688

Devonish, D. (2018). Effort-reward imbalance at work: the role of job satisfaction. Pers. Rev. 47 (2), 319-333.

Eagan, Jr., M. K., Jaeger, A. J., \& Grantham, A. (2015). Supporting the academic majority: policies and practices related to part-time faculty's job satisfaction. J. Higher Educ. 86 (3), 448-483.

Febrianti, N. T., \& SE, S. (2020). The Effect of Career Development and Motivation on Employee Performance Through Job Satisfaction in Pt Jabar Jaya Perkasa. International Journal of Business and Social Science Research, 1(2), 1-12.

Ferreira, V. L. (2015). Satisfação dos profissionais de saúde em meio hospitalar público, privado e parceria público-privada. Lisboa: Universidade Lusófona de Humanidades e Tecnologias.

Francisco, D. E. (2018). Avaliação de Clima Organizacional sobre a perceção dos colaboradores. EmpíricaBR Revista Brasileira de Gestão, Negócio e Tecnologia da Informação.

Freire, C. F. (2019). A relação entre as práticas de saúde e segurança no trabalho, clima de segurança e comportamentos de segurança: um estudo na área da saúde. Lisboa: Instituto Politécnico de Tomar.

Ganapathi, R. (2016). A study on work life balance and job satisfaction of women employees working in new private sector banks. Work, 1(2.91), 24-10.

Gobal, S. D. D. V., Hassan, A., Gobal, S. T. V., Baker, R., Yunus, M. A. W. M., \& Norazman, I. (2018). The effect of training on job satisfaction: A review paper. Retrieved March 18, 2020 from https://www.researchgate.net/publication/324886579 The Effect of Training on Job_Satisfaction_A_Review_Paper.

Ha, H. K., Jun, K. S., \& Bae, G. K. (2020). The Effects of Motivation on Job Satisfaction: Focused on Selfactualization. Culinary Science \& Hospitality Research, 26(9), 52-59.

Hariharasudan, A., \& Kot, S. (2018). A scoping review on digital English and Education 4.0 for Industry 4.0. Social Sciences, 7(11), 227-213. https://doi.org/10.3390/socsci7110227

Henriques, M. S. (2009). Satisfação Profissional, Cultura Organizacional e Desempenho Profissional. Faro: Universidade do Algarve.

Huang, X., Iun, J., Liu, A., \& Gong, Y. (2010). Does participative leadership enhance work performance by inducing empowerment or trust? The differential effects on managerial and non - managerial subordinates. Journal of organizational Behavior, 31(1), 122-143.

Ivancevich, J. M., Konopaske, R., \& Matteson. M. T. (2014). Organizational Behaviour and Management. New York: McGraw-Hill/Irwin.

Judge, T. A., Weiss, H. M., Kammeyer-Mueller, J. D., \& Hulin, C. L. (2017). Job attitudes, job satisfaction, and job affect: A century of continuity and of change. Journal of Applied Psychology, 102, 356-374.

Jusmin, A., Said, S., Bima, J., \& Alam, R. (2016). Specific Determinants of Work Motivation, Competence, Organizational Climate, Job Satisfaction and Individual Performance: A Study among Lecturers. Journal of Business Management Sciences, Vol. 4 No. 3.

Khan, A. H., Nawaz, M. M., Aleem, M., \& Hamed, W. (2012). Impact of job satisfaction on employee performance: An empirical study of autonomous medical institutions of Pakistan. African Journal of Business Management, 6(7), 2697-2705.

Kiarie, M., Maru, L., \& Cheruiyot, T. (2017). Leader personality traits and employee job satisfaction in the media sector, Kenya. The TQM Journal, 29(1), 133-146.

Koh, S., Ong, T., \& Samuel, A. (2017). The impacts of physical, psychological, and environmental factors on employees' job satisfaction among public accounting professionals in Malaysia. Asia-Pacific Manage. Accounting J. 12 (2), 129-156.

Kovacs, G., \& Kot, S. (2016). New logistics and production trends as the effect of global economy changes. Polish Journal of Management Studies, 14(2), 115-126. https://doi.org/10. 17512/pjms.2016.14.2.11

Kuenzi, M., Mayer, D. M. \& Greenbaum, R. L. (2020). Creating an ethical organizational environment: The relationship between ethical leadership, ethical organizational climate, and unethical behavior. Personnel Psychology. DOI: 10.1111/peps.12356.

Kumar-Bamel, U., Rangnekar, S., Stokes, P., \& Rastogi, R. (2013). Organizational climate and managerial effectiveness: An Indian perspective. International Journal of Organizational Analysis, 21(2), $198-218$. https://doi.org/10.1108/IJOA-09-2011-0514

Lambert, E. G., Hogan, N. L., Barton-Bellessa, S. M., \& Jiang, S. (2012). Examining the relationship between Supervisor and management trust and job burnout among correctional staff. Criminal Justice and Behavior, 39(7), 938-957.

Limm, H., Guendel, H., Heinmueller, M., Marten-Mittag, B., Nater, U. M., \& Siegrist, J. (2011). Stress management interventions in the workplace improve stress reactivity: a randomized controlled 
trial. Occupational and Environmental Medicine, 68, 126-133.

Lu, L., Lu, A. C. C., Gursoy, D., \& Neale, N. R. (2016). Work engagement, job satisfaction, and turnover intentions: A comparison between supervisors and line-level employees. International Journal of Contemporary Hospitality Management, 28(4), 737-761. https://doi. org/10.1108/IJCHM-07-2014-0360

Maamari, B. E., \& Majdalani, J. F. (2017). Emotional intelligence, leadership style and organizational climate. International Journal of Organizational Analysis, 25(2), 327-345. https:// doi.org/10.1108/IJOA-04-20161010

Maroco, J. (2018). Análise Estatística com o SPSS Statistics (7ª Edição). Lisboa: Report Number.

Martins, P., \& Martins, A. C. (1999). O regime de horário de trabalho e a vida social e doméstica: Satisfação e estratégias de coping - Um estudo numa amostra de enfermeiros. Análise Psicológica, 529-546.

Murphy, S. (2015). The optimistic workplace: Creating an environment that energizes everyone. New York: AMACON

Paais, M., \& Pattiruhu, J. R. (2020). Effect of motivation, leadership, and organizational culture on satisfaction and employee performance. The Journal of Asian Finance, Economics, and Business, 7(8), 577-58.

Parsian, N., \& Dunning, T. (2009). Developing and Validating a Questionnaire to Measure Spirituality: A Psychometric Process. Global Journal of Health Science 1(1), 1-11.

Purohit, B., \& Wadhwa, A. (2012). Organizational climate from view point of motivation in district hospital. Health, 04(07), 400-406. https://doi.org/10.4236/health.2012.47063

Putra, T. R. (2019). The role of organization climate and work motivation on job satisfaction in Aceh government health office. Journal of Academic Research in Economics (JARE), 98-106.

Riyadi, S. (2020). The Influence of Leadership Style, Individual Characteristics and Organisational Climate on Work Motivation, Job Satisfaction and Performance. International Journal of Innovation, Creativity and Change, 13(7), 662-677.

Roy, D. F. (2017). "Banana time" job satisfaction and informal interaction. In the Anthropology of Organizations. Routledge, pp. 31-41.

Rozman, M., Tominc, P., \& Milfelner, B. (2020). A comparative study using two SEM techniques on different samples sizes for determining factors of older employee's motivation and satisfaction. Sustainability, 12(6), 2189-2115. https://doi.org/10.3390/su12062189

Rozman, M., Treven, S., Mulej, M., \& Cancer, V. (2019). Creating a healthy working environment for older employees as part of social responsibility. Kybernetes, 48(5), 1045-1059. https://doi.org/10.1108/K-122017-0483

Santo, E. E. (2016). A perceção do Clima Organizacional na Amarsul. S.A. Setúbal: Instituto Politécnico de Setúbal.

Schaufeli, W. B. (2016). Heavy work investment, personality and organizational climate. Journal of Managerial Psychology, 31(6), 1057-1073. https://doi.org/10.1108/JMP-07-2015- 0259.

Schneider, B., Ehrhart, M. G., \& Macey, W. H. (2016). Organizational climate and culture. In G. J. Boyle, J. G. O'Gorman, \& G. J. Fogarty (Eds.), Sage benchmarks in psychology. Work and organisational psychology: Research methodology; Assessment and selection; Organisational change and development; Human resource and performance management; Emerging trends: Innovation/globalisation/technology (pp. 299332). Sage Publications Inc.

Schuler, R. S. (2015). Definition and conceptualization of stress in organizations. Organizational Behavior and human performance, 25(2), 184-215.

Schulte, P. A., Guerin, R. J., Schill, A. L., Bhattacharya, A., Cunningham, T. R., Pandalai, S. P., ... Stephenson, C. M. (2015). Considerations for incorporating "well-being" in public policy for workers and workplaces. American Journal of Public Health (AJPH).

Segatto, M. B., \& Wachowicz, M. C. (2017). Clima Organizacional como factor contribuinte para a motivação e a satisfação no trabalho. Revista Científica Semana Acadêmica. Fortaleza, ano MMXVII, Nº 000105.

Shuck, B., Adelson, J. L., \& Reio, T. G. (2017). The Employee Engagement Scale: Initial Evidence for Construct Validity and Implications for Theory and Practice. Human Resource Management, 56(6), 953977. https://doi.org/10.1002/hrm.21811

Smith, K., Davis, M., Malone, C. F., \& Owens-Jackson, L. A. (2020). Faculty That Look Like Me: An Examination of HBCU Accounting Faculty Motivation and Job Satisfaction. Available at SSRN 3744399.

Sobaih, A. E. E., \& Hasanein, A. M. (2020). Herzberg's theory of motivation and job satisfaction: Does it work for hotel industry in developing countries? Journal of Human Resources in Hospitality \& Tourism, 19(3), 319-343.

Stefurak, T., Morgan, R., \& Johnson, R. B. (2020). The Relationship of Public Service Motivation to Job Satisfaction and Job Performance of Emergency Medical Services Professionals. Public Personnel Management, 49(4), 590-616.

Suzuki, A., Mano, Y., \& Abebe, G. (2018). Earnings, savings, and job satisfaction in a labour-intensive export 
sector: evidence from the cut flower industry in Ethiopia. World Dev. 110, 176-191.

Tesluk, P., Farr, J., \& Klein, S. (2011). Influences of Organizational Culture and Climate on Individual Creativity. Journal of Creative Behaviour.

Viitala, R., Tanskanen, J., \& Seantti, R. (2015). The connection between organizational climate and well-being at work. International Journal of Organizational Analysis, 23(4), 606-620. https://doi.org/10.1108/IJOA10-2013-0716

Zacher, H., \& Yang, J. (2016). Organizational Climate for Successful Aging. Frontiers in Psychology.

Zou, M. (2018). Understanding the gender difference in job satisfaction: A work orientation perspective. Employment and Society 29:1, 3-22. Retrieved from www.equalsoc.org/./form\%5B1\%5D.pdf 